\title{
Penerapan Model Experiential Learning untuk Meningkatkan Keterampilan Menulis Karangan Narasi Siswa Kelas I SDN 3 Selang Tahun Ajaran 2017/2018
}

\author{
1,2,3 Universitas Sebelas Maret \\ yenijayanti69@gmail.com
}

Yeni Jayanti ${ }^{1}$, Suhartono ${ }^{2}$, Ratna Hidayah ${ }^{3}$

\section{Article History}

accepted 01/02/2019

\begin{abstract}
The objective of this research is to improving narrative essay writing skills for students. This research is a collaborative Classroom Action Research (CAR) conducted within three cycles. Each cycle has two meetings consisting of planning, action, observation, and reflection. The result of this research shows that the implementation of experiential learning model can improve narrative essay writing skills of students. The percentage of learning outcomes in the first cycle $59.65 \%$, in the second cycle $78.37 \%$, and in the third cycle $92.11 \%$ respectively. The conclusion of this research is the implementation of experiential learning model can improve narrative essay writing skills for the fourth grade students of SDN 3 Selang in the academic year of 2017/2018.
\end{abstract}

Keywords: experiential learning, writing skills, narrative essay.

\section{Abstrak}

Tujuan penelitian ini untuk meningkatkan keterampilan menulis karangan narasi siswa. Penelitian dilaksanakan dalam tiga siklus dan tiap siklus terdiri dari 2 pertemuan yang meliputi perencanaan, pelaksanaan, observasi, dan refleksi. Hasil penelitian menunjukkan penerapan model Experiential Learning dapat meningkatkan keterampilan menulis karangan narasi siswa. Persentase ketuntasan siswa pada siklus I sebesar $59,65 \%$, siklus II $78,37 \%$, dan siklus III 92,11\%. Simpulan penelitian ini adalah penerapan model Experiential Learning dapat meningkatkan keterampilan menulis karangan narasi siswa kelas IV SDN 3 Selang tahun ajaran 2017/2018.

Kata Kunci: Experiential Learning, Keterampilan Menulis, Karangan Narasi 


\section{PENDAHULUAN}

Bahasa Indonesia merupakan salah satu mata pelajaran yang diajarkan dari mulai kelas 1 sampai dengan kelas 6. Pembelajaran Bahasa Indonesia terdiri dari empat keterampilan yang harus dikuasai siswa, yaitu keterampilan menyimak, keterampilan berbicara, keterampilan membaca, dan keterampilan menulis (Tarigan, 2013: 1). Berdasarkan keempat keterampilan bahasa tersebut, keterampilan menulis lebih sukar dilakukan karena keterampilan menulis merupakan kegiatan yang produktif atau menghasilkan. Iskandarwassid dan Sunendar (2011: 248) menyatakan menulis sebagai bentuk perwujudan kemampuan dan keterampilan bahasa yang paling akhir dikuasai setelah mendengar, berbicara, dan membaca.

Pembelajaran menulis di SD dibagi menjadi dua tahapan, yaitu menulis permulaan dan menulis lanjut. Menulis permulaan yaitu saat siswa baru belajar memegang alat tulis sampai menghasilkan sebuah tulisan, sedangkan menulis lanjut yaitu kegiatan menulis yang lebih beragam seperti membuat karangan. Mengarang pada hakikatnya ialah mengungkapkan atau menyampaikan gagasan dalam bentuk kalimat, paragraf, maupun karangan yang utuh menggunakan bahasa tulis (Suparno \& Yunus, 2007: 3.1). Terdapat berbagai macam karangan salah satunya adalah karangan narasi. Narasi merupakan sebuah bentuk karangan yang menceritakan tentang rangkaian peristiwa atau kejadian berdasarkan hal yang pernah terjadi maupun yang direkayasa. Narasi dapat berupa pengalaman pribadi, informasi, cerita imajinasi, atau biografi yang tersusun secara kronologis.

Berdasarkan hasil observasi, kondisi awal yang terdapat di lapangan menunjukkan bahwa keterampilan menulis karangan narasi siswa masih tergolong rendah. Faktor terjadinya hal tersebut dikarenakan: 1) pembelajaran yang disampaikan guru masih bersifat satu arah, 2) model pembelajaran yang digunakan guru belum berorientasi pada siswa, 3) kurangnya minat siswa terhadap pembelajaran Bahasa Indonesia, dan 4) siswa kesulitan dalam membayangkan apa yang akan mereka tulis.

Salah satu model yang dapat diterapkan dalam pembelajaran menulis karangan narasi adalah model Experiential Learning. Cahyani (2012: 164) berpendapat jika model Experiential Learning dapat memberikan keaktifan kepada siswa untuk membangun pengetahuan, keterampilan, dan sikap melalui pengalaman yang mereka dapatkan dari dunia nyata. Kolb (Rosier, dkk, 2016: 487) menyatakan bahwa model Experiential Learning memiliki empat langkah yaitu: 1) concrete experience (pengalaman nyata), 2) reflection observation (observasi refleksi), 3) abstract conceptualization (penyusunan konsep abstrak), dan 4) active experimentation (eksperimen aktif).

Pemilihan model Experiential Learning dikarenakan model ini memberikan kesempatan pada siswa untuk mengembangkan kemampuannya berdasarkan pengalaman yang telah dimiliki. Melalui model ini siswa tidak hanya mendapatkan pengetahuan tentang konsep-konsep saja, tetapi siswa juga mendapatkan pengalaman nyata yang akan menumbuhkan keterampilan melalui penugasanpenugasan nyata. Dengan demikian, keterampilan menulis siswa diharapkan dapat mengalami peningkatan.

Berdasarkan fakta-fakta yang telah ditemukan, peneliti tertarik melakukan penelitian tindakan kelas kolaboratif sebagai upaya untuk melakukan perbaikan terhadap pembelajaran bahasa Indonesia dengan judul "Penerapan Model Experiential Learning untuk Meningkatkan Keterampilan Menulis Karangan Narasi Siswa Kelas IV SDN 3 Selang Tahun Ajaran 2017/2018".

Rumusan masalah dari penelitian ini adalah apakah model Experiential Learning dapat meningkatkan keterampilan menulis karangan pada siswa kelas IV SDN 3 Selang tahun ajaran 2017/2018? 
Tujuan penelitian ini adalah untuk meningkatkan keterampilan menulis karangan pada siswa kelas IV SDN 3 Selang tahun ajaran 2018/2018 melalui penerapan model Experiential Learning.

\section{METODE}

Penelitian tindakan kelas kolaboratif ini dilaksanakan di SDN 3 Selang. Kegiatan penelitian ini telah dilaksanakan selama enam bulan yaitu dari September 2017 sampai dengan Februari 2018. Subjek penelitian ini adalah guru kelas IV dan siswa kelas IV SDN 3 Selang tahun ajaran 2017/2018 yang berjumlah 19 siswa, terdiri atas 7 siswa laki-laki dan 12 siswa perempuan.

Data yang diambil pada penelitian ini yaitu data kuantitatif dan data kualitatif. Data kuantitatif berupa nilai tes keterampilan menulis karangan siswa, data kualitatif berupa hasil observasi dan wawancara mengenai pelaksanaan pembelajaran di kelas dengan menerapkan model Experiential Learning yang dilakukan oleh guru.

Teknik pengumpulan data yang digunakan pada penelitian ini yaitu teknik tes dan teknik non tes yang berupa observasi dan wawancara. Alat pengumpulan data berupa lembar tes, lembar observasi, dan pedoman wawancara. Validitas data menggunakan triangulasi sumber dan triangulasi teknik. Analisis data menggunakan analisis model interaktif, meliputi: reduksi data, penyajian data, dan penarikan kesimpulan.

Sebagai dasar untuk mengetahui keberhasilan penelitian, peneliti menetapkan indikator kinerja penelitian sebesar 85\% yang meliputi tiga aspek, yaitu: (1) penerapan langkah-langkah model Experiential Learning pada pembelajaran menulis karangan narasi, (2) aktivitas siswa saat mengikuti kegiatan pembelajaran sesuai dengan langkah-langkah penerapan model Experiential Learning, dan (3) keterampilan menulis karangan siswa.

\section{HASIL DAN PEMBAHASAN}

Penerapan model Experiential Learning dalam pembelajaran menulis karangan narasi dilaksanakan selama tiga siklus, setiap siklus terdiri dari dua pertemuan melalui empat langkah, yaitu: (1) concrete experience (pengalaman konkret), (2) reflective observation (obsevasi reflektif), (3) abstract conceptualization (konseptualisasi abstrak), dan (4) active experimentation (percobaan aktif).

Nilai keterampilan menulis karangan narasi siswa siswa diperoleh dari rata-rata pencapaian tigas aspek penilaian keterampilan menulis karangan narasi pada saat siswa mengerjakan evaluasi berupa menulis karangan, meliputi: (1) ruang lingkup isi, (2) penggunaan bahasa, dan (3) penggunaan ejaan.

Penerapan model Experiential Learning untuk meningkatkan keterampilan menulis karangan pada siswa kelas IV SDN 3 Selang dinyatakan berhasil. Keberhasilan tersebut ditunjukkan dengan peningkatan nilai tes keterampilan menulis karangan narasi siswa pada setiap siklus, sehingga persentase ketuntasan belajar siswa mencapai indikator kinerja penelitian yang telah ditetapkan sebesar $85 \%$ dengan KKM 70. Peningkatan nilai tes keterampilan menulis siswa dapat dilihat padal tabel 1. berikut: 
Tabel. 1. Perbandingan Nilai Tes Keterampilan Menulis Karangan Narasi Siswa pada Siklus I,II, dan III

\begin{tabular}{cccc}
\hline Siklus & \begin{tabular}{c} 
Nilai \\
Rata- \\
\cline { 3 - 4 }
\end{tabular} & \multicolumn{2}{c}{ Persentase (\%) } \\
\cline { 3 - 4 } rata & Tuntas & $\begin{array}{c}\text { Tidak } \\
\text { Tuntas }\end{array}$ \\
\hline I & 71,27 & 59,65 & 40,35 \\
\hline II & 79,19 & 78,37 & 21,64 \\
\hline III & 85,82 & 92,11 & 7,90 \\
\hline
\end{tabular}

Berdasarkan data pada tabel 1. di atas, dapat diketahui adanya peningkatan nilai rata-rata keterampilan menulis karangan siswa dari siklus I sampai dengan siklus III. Dari hasil tersebut, menunjukkan bahwa keterampilan menulis karangan siswa pada siklus I, II, dan III mengalami peningkatan.

Pada aspek ruang lingkup isi, siklus I hasil karangan narasi siswa tersusun secara tidak runtut, dan isi gagasan yang dikemukakan siswa masih ada yang belum sesuai dengan judul dan tema yang telah ditentukan. Pada siklus II dan III hasil karangan narasi siswa sudah tersusun secara runtut dan sudah sesuai dengan judul dan tema yang telah ditentukan. Pada aspek penggunaan bahasa, siklus I siswa masih banyak yang menggunakan kosakata bahasa daerah dan pemilihan kosakata sederhana. Karangan siswa juga tersusun atas pengulangan kalimat di setiap paragrafnya, sehingga terkesan monoton. Pada siklus II dan III kosakata bahasa daerah sudah berkurang, pemilihan kosakata lebih bervariatif, dan pola kalimat yang digunakan sudah tepat. Kalimat-kalimat antar paragraf saling berkaitan dan mudah dipahami. Pada aspek penggunaan ejaan, siklus I siswa belum memperhatikan penggunaan ejaan dalam menulis karangan narasi. Banyak terjadi kesalahan seperti dalam penggunaan tanda titik dan huruf huruf kapital. Pada siklus II dan III siswa sudah mulai memperhatikan penggunaan ejaan dan tanda baca, sehingga hanya terdapat sedikit kesalahan. Selain itu, siswa juga menggunakan tanda koma (,) dan tanda petik (“..."). Hal tersebut sesuai dengan penelitian yang dilakukan oleh Sriani, Sutama, \& Darmayanti (2015), bahwa model Experiential Learning dapat meningkatkan keterampilan menulis siswa.

Hasil penelitian menunjukkan bahwa penerapan model Experiential Learning dapat meningkatkan perilaku positif siswa yaitu, siswa menjadi lebih semangat dan aktif dalam mengikuti pembelajaran, karena siswa belajar berdasarkan pengalamannya sendiri. Selain itu, model Experiential Learning dapat meningkatkan kemampuan berpikir kreatif siswa untuk menuangkan pengalamannya menjadi sebuah karangan, sehingga nilai hasil tes menulis karangan siswa dapat mencapai KKM. Hal ini diperkuat dengan penelitian yang telah dilakukan oleh Payana (2014) bahwa penerapan model Experiential Learning dapat meningkatkan semangat belajar serta kemampuan berpikir kreatif siswa dalam menulis karangan, sehingga nilai keterampilan menulis karangan siswa dapat mencapai KKM. 


\section{SIMPULAN}

Berdasarkan pembahasan hasil penelitian yang telah dijelaskan di atas, dapat disimpulkan bahwa penerapan model Experiential Learning dalam pembelajaran menulis karangan narasi dapat meningkatkan keterampilan menulis karangan narasi pada siswa kelas IV SDN 3 Selang tahun ajaran 2017/2018. Adapun saran yang dapat peneliti sampaikan, yaitu: (1) guru hendaknya menerapkan model Experiential Learning sebagai alternatif untuk meningkatkan keterampilan menulis karangan di kelas IV; (2) pihak sekolah hendaknya mengenalkan model pembelajaran yang inovatif, salah satunya yaitu Experiential Learning kepada guru, sehingga guru dapat meningkatkan proses dan hasil pembelajaran; (3) bagi peneliti lain yang akan melaksanakan penelitian sejenis, model Experiential Learning dapat diterapkan pada mata pelajaran yang lain.

\section{DAFTAR PUSTAKA}

Cahyani, I. (2012). Pembelajaran Menulis Berbasis Karakter dengan Pendekatan Experiential Learning. Bandung: Program Pendidikan Dasar SPS UPI.

Iskandarwassid \& Sunendar, D. (2011). Strategi Pembelajaran Bahasa. Bandung: PT Remaja Rosdakarya.

Payana, W.D. (2014). Pengaruh Model Pembelajaran Experiential Learning Terhadap Kemampuan Menulis Karangan Narasi Siswa kelas XI SMK Tarbiyah Islamiyah Hamparan Perak Tahun Pembelajaran 2012/2013. Jurnal asas: jurnal sastra, 3, (4), 1-11. Diperoleh pada 10 Februari 2018.

Rosier, J., dkk. (2016). The benefits of embedding experiential learning in the education of planners. Planning Practice \& Research, 31 (5), 486-499. Diperoleh pada 30 Oktober 2017.

Sriani, Sutama, dan Damayanti. (2015). Penerapan Model Pembelajaran Experiential Learning untuk Meningkatkan Kemampuan Menulis Paragraf Deskripsi Pada Siswa Kelas VII B SMP Negeri 2 Tampaksiring. Jurnal Pendidikan Bahasa dan sastra Indonesia, 3 (1), 1-11. Diperoleh pada 29 Oktober 2017.

Suparno \& Yunus, M. (2007). Keterampilan dasar Menulis. Jakarta: Universitas Terbuka.

Tarigan. (2013). Menulis Sebegai Suatu Keterampilan Berbahasa. Bandung: CV Angkasa. 